\title{
Entrepreneurial intentions of students and deterrence of entrepreneurial education opportunities: the case of Uzbekistan
}

\section{Yuliya PARAMONOVA ${ }^{1}$}

Westminster International University in Tashkent

\begin{tabular}{l} 
ARTICLE INFO \\
\hline Article history: \\
Received October 2021 \\
Received in revised form \\
15 October 2021 \\
Accepted 20 November 2021 \\
Available online \\
15 December 2021 \\
\hline
\end{tabular}

\section{Keywords:}

business development, education,

attitudes towards

entrepreneurship,

economic development, business venture, students.

\begin{abstract}
This study uses an econometric approach to determine the impact of entrepreneurial business education on the entrepreneurial intentions of students in Uzbekistan. The work is based on extensive research by international experts who determine various antecedents of entrepreneurial intention based on the Theory of Planned Behavior (Eisen, 1991). Such as the attitude to entrepreneurship, perceived behavioral control and subjective norms. In studies of another direction, the importance of entrepreneurial education (PO) in stimulating entrepreneurial intention is discussed. Which then leads to entrepreneurial behavior, namely, opening your own business. The questionnaire prepared by the author is based on a 5-point Likert scale and consists of several separate sections, each of which relates to the above factors. The results of the ordered logistic regression indicate a significant relationship between entrepreneurship education and attitudes to entrepreneurship. The attitude, in turn, has a significant impact on the entrepreneurial intentions of students, accounting for about $5 \%$ of the variation. The results obtained will pave the way for future developments in the field of development of entrepreneurial education. Also, they will help to form a more effective state policy in the field of education, in order to increase the development of entrepreneurship in Uzbekistan.
\end{abstract}

2181-1415/C 2021 in Science LLC.

DOI: https://doi.org/10.47689/2181-1415-vol2-iss11/S-pp116-125

This is an open access article under the Attribution 4.0 International (CC BY 4.0) license (https://creativecommons.org/licenses/by/4.0/deed.ru)

\footnotetext{
$1 \mathrm{PhD}$ student at Westminster International University in Tashkent. Tashkent, Uzbekistan.

E-mail: yv.paramonova@gmail.com
} 


\section{Talabalarda tadbirkorlik niyati va tadbirkorlik ta'limining mo'tadil ta'siri: O'zbekiston misolida}

\author{
Kalit so'zlar: \\ biznesni rivojlantirish, \\ ta'lim, \\ tadbirkorlikka munosabat, \\ iqtisodiy rivojlanish, \\ biznes tashabbusi, \\ talabalar.
}

\begin{abstract}
ANNOTATSIYA
Ushbu tadqiqot ishida tadbirkorlik ta'limining O'zbekiston universitetlari talabalarining tadbirkorlik niyatlariga ta'sirini aniqlashda ekonometrik yondashuv qo'llaniladi. Ish rejalashtirilgan xulq-atvor nazariyasi (TPB) asosida tadbirkorlik niyatining turli xil oldingi holatlarini aniqlagan xalqaro mualliflar tomonidan olib borilgan keng qamrovli oldingi tadqiqotlarga asoslanadi, masalan, tadbirkorlikka bo'lgan munosabat, qabul qilingan xatti-harakatlar nazorati va subyektiv me'yorlar. Adabiyotlarning yana bir oqimi tadbirkorlik xulq-atvoriga olib keladigan tadbirkorlik niyatini rivojlantirishda tadbirkorlik ta'limining (EE) ahamiyatini muhokama qildi. Muallif tomonidan tayyorlangan anketa 5 ballik likert shkalasi asosida tuzilgan va har biri yuqorida qayd etilgan omillarga tegishli bo'lgan bir nechta alohida bo'limlardan iborat. Buyurtma qilingan logistik regressiya natijalari tadbirkorlik ta'limi va tadbirkorlikka bo'lgan munosabat o'rtasidagi muhim bog'liqlikni ko'rsatadi. O'z navbatida, munosabat talabalarning tadbirkorlik niyatiga sezilarli ta'sir ko'rsatadi, bu ularning 5\% ini tashkil qiladi. Natijalar tadbirkorlik ta'limini rivojlantirish sohasidagi kelajakdagi o'zgarishlarga yo'l ochadi va O'zbekistonda tadbirkorlikni rivojlantirish bo'yicha ta'lim sohasida yanada samarali davlat siyosatini shakllantirishga yordam beradi.
\end{abstract}

\section{Предпринимательские намерения студентов и сдерживание возможностей предпринимательского образования: на примере Узбекистана}

\footnotetext{
Ключевые слова:

развитие бизнеса, образование,

отношение к

предпринимательству, экономическое развитие, бизнес структуры, студенты.
}

\section{АННОТАЦИЯ}

Данное исследование, применяет эконометрический подход для определения влияния предпринимательского бизнес образования на предпринимательские намерения студентов Узбекистана. Работа, основана на обширных исследованиях международных специалистов, которые определяют различные антецеденты предпринимательского намерения на основе Теории запланированного поведения (Айзен, 1991). Такие как, отношение к предпринимательству, воспринимаемый поведенческий контроль и субъективные нормы. В исследованиях другого направления обсуждается важность предпринимательского образования (ПО) в стимулировании предпринимательского намерения. Которое, затем приводит к предпринимательскому поведению, а именно, к открытию собственного бизнеса. Подготовленный автором опросник основан на 5-балльной шкале Лайкерта и состоит из нескольких отдельных разделов, каждый из 


\begin{abstract}
которых относится к указанным выше факторам. Результаты упорядоченной логистической регрессии указывают на значительную взаимосвязь, между образованием в области предпринимательства и отношением к предпринимательству. Отношение, в свою очередь, оказывает значительное влияние на предпринимательские намерения студентов, составляя около 5\% вариации. Полученные результаты, проложат путь для будущих разработок в области развития предпринимательского образования. Также, помогут сформировать более эффективную государственную политику в области образования, с целью увеличения развития предпринимательства в Узбекистане.
\end{abstract}

\title{
INTRODUCTION AND PROBLEM STATEMENT
}

In the current decade the rate of youth unemployment throughout the world has reached new heights at nearly 15\% (https://data.worldbank.org/indicator/SL.UEM. 1524.ZS). This problem has been exacerbated by the Covid-19 pandemic, the ensuing lockdowns and the shutting down of businesses globally. In Uzbekistan in particular the level of unemployment among people under 30 years old amounted to 15.8\% (data.gov.uz, 2021) while unemployed women made up $13.3 \%$ of the total unemployed. A number of governments and international scientists have suggested that entrepreneurship education (hereinafter EE) can be one of the most plausible solutions to this pertinent issue as it helps spur entrepreneurship development in a country. As an example, in 2004 the European Commission had advised all the EU member-countries to include EE into the curricula of national educational institutions, starting from primary schools through universities (data). WorldBank has made a further step in promoting EE as one of the pivotal factors in decreasing unemployment rates (WorldBank, 2008). Extensive works of international researchers have established a positive correlation between levels of entrepreneurial activity and EE (ref). Entrepreneurial activity in turn is considered to be the major driver of economic growth, innovation and employment. (Giacomin et al, 2011, others).

Universities have long been considered as stimulating for economic activity as they generate knowledge and drive technological development (Goldstein and Renault 2004; Lööf and Broström 2008). It is essential that universities offer EE that results in the feasible outcome, i.e. an entrepreneurial action. As numerous empirical studies suggest entrepreneurship can be taught (Gatewood et al., 2002; Mitra \& Matlay, 2004; Kuratko, 2005; Harris and Gibson, 2008; Henry et al. 2005; Falkang and Alberti, 2000; Kirby, 2002; Kuratko, 2003) and a deliberate and conscious decision to start an entrepreneurial career can be fostered (Krueger et al. 2000). This has caused a drastic upward shift in the number and status of entrepreneurial programs at higher educational institutions globally (Finkle and Deeds, 2001; Kurakto, 2005; Matlay, 2005). Although the benefits of EE have been confirmed by many scholars and educators, the moderating effect of EE programs on entrepreneurial competencies and entrepreneurial intent has been largely underinvestigated (Sánchez, 2010).

Uzbekistan in the past few years has also undergone structural changes and reforms aimed at enhancing entrepreneurial development, both within higher educational settings and within the country's overall business activity. A few notable measures were proposed 
which include in particular the development of the university based innovation labs and incubation centers as well as enhancing EE in high schools and onwards. However, a comprehensive policy framework enabling the spread and efficiency of EE is still lacking. In addition to that to the author's best knowledge no empirical research exists in Uzbekistan regarding the impact of current EE programs on students' entrepreneurial intent. Thus the current study aims to fill this gap and understand whether or not EE has a mediating impact on students' entrepreneurial intent.

The following Research question and objectives have been proposed:

Q: Does EE in higher educational institutions in Uzbekistan have a mediating effect on students' entrepreneurial intent?

The following objectives were raised to achieve the purpose of the study:

1) To identify a moderating role of EE on entrepreneurial intention among students of two international universities in Uzbekistan;

2) To present the methodology of the empirical research;

3) To research the impact of entrepreneurial education on the intention of the students to start-up business ventures in Uzbekistan.

\section{THEORETICAL CONCEPTS}

Consistent with the entrepreneurial literature, the decision to start a company is preceded by the intention to pursue an entrepreneurial path and to become an entrepreneur (Reynolds and White, 1997; Blanchflower et al., 2001; Hisrich et al., 2005, Passaro, 2018). Hence researchers had long been focusing on entrepreneurial intention as the best predictor of a planned behavior (Krueger et al., 2000) and thus it has become a prominent field in entrepreneurial research (Fayolla and Linan, 2012). Several theoretical frameworks have been introduced in order to explore the relationship between entrepreneurial intention and its various antecedents. Theory of planned behavior (TPB) provides a strong theoretical foundation for that linkage as well as for the linkage of entrepreneurial intent and entrepreneurial action (Ajzen 1991). The model that has been robustly tested by prominent scholars (Karimi, 2011, Engle et al., 2010) proposes that the stronger an individual's intention to engage in a specific behavior the more likely that he or she will actually perform it (Peterman and Kennedy 2003; Guerrero et al. 2008; Krueger et al. 2000.) The intention itself is the outcome of three antecedents such as (a) attitude toward behavior, (b) subjective norms and (c) perceived behavioral control (Kolvereid, 1996a; Krueger et al., 2000; Autio et al., 2001; Kennedy et al.; 2003; Angle et al., 2010).

Systemized results of scientific papers indicate different aspects of entrepreneurial intention. While some authors focus rather on the individual-level factors of entrepreneurship, others also include regional factors such as the country's economy and institutional development. Yet another stream of authors have pointed out the importance and relevance of entrepreneurial education (EE) for the entrepreneurial intention (Remiekiene, Lee, et. al., 2005; Turker, Selcuk, 2009; De Jorge-Moreno, et. al., 2012. They argue that EE is a strong antecedent to entrepreneurial intent and found that its effect on the latter is mediated, at least partially, through its effect on TPB's constructs (Rauch and Hulsink, 2015, Ridrigues et al., 2010, Fini et al., 2012; Vanevenhoven and Liguori, 2013). Linãn et. al. (2011) advances that personal attitudes and perceived behavioral control are the main factors that build up an entrepreneurial intention. Lack of knowledge related to entrepreneurial activity such as business and management, accountancy and administration knowledge has been found to be one of the main barriers in 
entrepreneurial intention (Pruett et al, 2009). Fayolle and Klandt (2006) in their works regarded the links of entrepreneurial education to behavior and mind-set. EE helps students develop specific skills that result in a more efficient opportunity recognition, decision-making and ease of networking (Fayolle and Klandt (2006). According to these authors, Entrepreneurship education as it affects the minds of individuals also impacts their attitudes, values and beliefs which in turn enhance their entrepreneurial intention. It is also important to note yet another stream of literature where the relationship between EE and entrepreneurial intention has been found inconsiderate (Rayolle and Gailly, 2009; Graenetitz et al, 2010; Sanchez, 2013). Some had even identified EE having a counter-effect on entrepreneurial intention as individuals that had been exposed to entrepreneurial learning may be discouraged by realistic vision of what it takes to start a company as well as challenges associated with managing and growing a firm (Oosterbeek et al., 2010; Fayolle and Gailly, 2015).

Startup or entrepreneurial education which usually encompasses a process of business-planning, visits to business entities and attendance of local entrepreneurs-guest speakers (Linan et al., 2010, Honig, 2004). Thus, entrepreneurial training can help strengthen student entrepreneurial intention and behavior through enhancement of their knowledge and skills (Barbosa et al. (2008). More recently, some researchers have also considered a subjectivist theory of entrepreneurship that focuses on individuals, their knowledge, resources and skills, and the processes of discovery and creativity, which constitute the heart of entrepreneurship (Kor et al. 2007). Some scholars in their entrepreneurship theory focused on individuals and the knowledge and skills they possess as well as how they express their creativity and have concluded that entrepreneurs' personal knowledge strongly impacts the decision to start a venture (Luthje and Franke 2003). Thus, with the prevalence of intention models in entrepreneurship research many authors point to the relevance of additional variables such as EE and institutional knowledge (authors). Kuratko (2005) or Florin et al. (2007), have argued that EE can strongly influence attitudes toward entrepreneurship. Universities are the major medians responsible for providing entrepreneurial education therefore should they ensure adequate level of knowledge and inspiration with respect to business activities the intention of students to start entrepreneurial careers will increase (Turker, Selcuk (2009).

The following empirical analysis aims to shed light on the relevance of one of these variables, Entrepreneurial education, in explaining students' entrepreneurial intention. student's EI

H1: The higher the perceived relevance of the course content the stronger the

H2: The higher the perceived relevance of the course content, the higher the student's attitude towards the entrepreneurship

H3: The higher the perceived relevance of the course content, the stronger the positive impact of attitudes on EI

\section{METHODOLOGY}

This paper follows an empirical analysis which tries to explore the impact of independent variables on shaping Entrepreneurial intentions in students. For this purpose, the Questionnaire survey was chosen as the most appropriate method for research designed as a 5-point likert-scale divided into the following main sections: Attitudes towards entrepreneurship, Perceived impact of social norms, and perceived Locus of Control. The questionnaires were created using the Microsoft forms platform and 
submitted digitally via the Telegram chats to students of different undergraduate university programs such as marketing, business and management, financial management and accounting. The total number of respondents reached 160 . The aim of this study is to identify the impact of business-related educational courses on entrepreneurial intention of students in Uzbekistan. Chronbach Alpha was run on Stata to test internal reliability between items in the scale. The ordinal linear regression was then used to test the impact of the IVs on DVs The results will help in formulating future agenda pertaining to improvements and regulations of educational programs of business-related and entrepreneurial modules in other local universities country-wide as to extend the positive impact this education has on students' intention to start their own ventures and thus spur entrepreneurial development in Uzbekistan.

\section{RESULTS}

Table 1. Cronbach alpha ei ee content attitudes loc subnorms

Test scale $=$ mean (unstandardized items)

Average interitem covariance: .1187279

Number of items in the scale: 5

Scale reliability coefficient: $\quad 0.5246$

The results for the Cronbach Alpha of 0.53 coefficient in Table 1 are indicative of a relatively good scale quality. Prior correlation analysis has resulted in an insignificant correlation of two variables Social norms (Socnorms) and Locus of control (Loc) with other variables in the model, therefore they have been excluded from the subsequent regression analysis. Regression analysis between the DV Entrepreneurial intention (EI) and IV ee content showed statistically insignificant relations between the variables thus rejecting our Hypothesis 1 . The binary ordinal logistic regression in Table 2 demonstrates a statistically significant relationship between the DV EI and IV Attitudes with a relatively high coefficient of 1.08. This variable itself explains c.5\% of variations in students' entrepreneurial intentions. Our Hypothesis 2 was further confirmed by the regression model in Table 3, which represents a statistically significant impact of IV Entrepreneurship education content (ee content) on DV Attitudes towards entrepreneurship (Attitudes). Although previous analysis has revealed a statistically insignificant direct relationship between variables ee content and EI we included the variable in our ordered logistic analysis to test the Hypothesis 3 which aimed to identify whether the perceived relevance of entrepreneurial educational content would positively mediate impact of attitudes on entrepreneurial intent. Table 4 model indicates that with the addition of ee content variable the positive coefficient of IV Attitudes is enhanced therefore revealing an indirect impact of entrepreneurial education on entrepreneurial intention via the attitudes construct.

Table 2. Original logistic regression logit ei attitudes

Iteration 0: $\log$ likelihood $=-257.2653$

Iteration 1: $\log$ likelihood $=-243.14322$

Iteration 2: $\log$ likelihood $=-242.90951$

Iteration 3: $\log$ likelihood $=-242.90881$

Iteration 4: $\log$ likelihood $=-242.90881$

Ordered logistic regression

Number of obs $=160$

$$
\begin{array}{lll}
\mathrm{LR} \operatorname{chi} 2(1) & = & 28.71 \\
\text { Prob }>\text { chi2 } & = & 0.0000
\end{array}
$$




\begin{tabular}{|c|c|c|c|c|c|c|c|}
\hline Log likeliho & ood $=-242.9$ & 881 & Ps & seudo R2 & $=$ & $=0$ & 558 \\
\hline ei $\mid$ & Coef. Std. E & Err. $\quad \mathrm{Z} \quad \mathrm{P}>$ & & $95 \%$ Conf & Inte & erval] & \\
\hline attitudes | & | 1.082781 & .2136198 & 5.07 & 0.000 & 6640 & 0942 & 1.501469 \\
\hline /cut1| & -2994185 & 1.047676 & & -2.3528 & 25 & 1.75 & 988 \\
\hline /cut2 | & .8632122 & .88332 & & -.868063 & & .5944 & \\
\hline /cut3 | & 2.932615 & .866324 & & 1.23465 & 14 & 4.630 & \\
\hline /cut4 & 4.763342 . & 9164756 & & 2.9670 & 83 & 6.559 & 602 \\
\hline /cut5 & 6.068997 & .9506788 & & 4.2057 & 01 & 7.932 & 294 \\
\hline /cut6 | & . & .9811592 & & 5.1105 & & 8.956 & 659 \\
\hline
\end{tabular}

Table 3. . ologit attitudes eecontent

Iteration 0: $\log$ likelihood $=-322.46716$

Iteration 1: $\log$ likelihood $=-319.30518$

Iteration 2: $\log$ likelihood $=-319.29613$

Iteration 3: $\log$ likelihood $=-319.29613$

Ordered logistic regression $\quad$ Number of obs $=160$

$$
\begin{array}{lll}
\text { LR chi2 }(1) & = & 6.34 \\
\text { Prob }>\text { chi2 } & = & 0.0118
\end{array}
$$

Log likelihood $=-319.29613 \quad$ Pseudo R2 $\quad 0.0098$

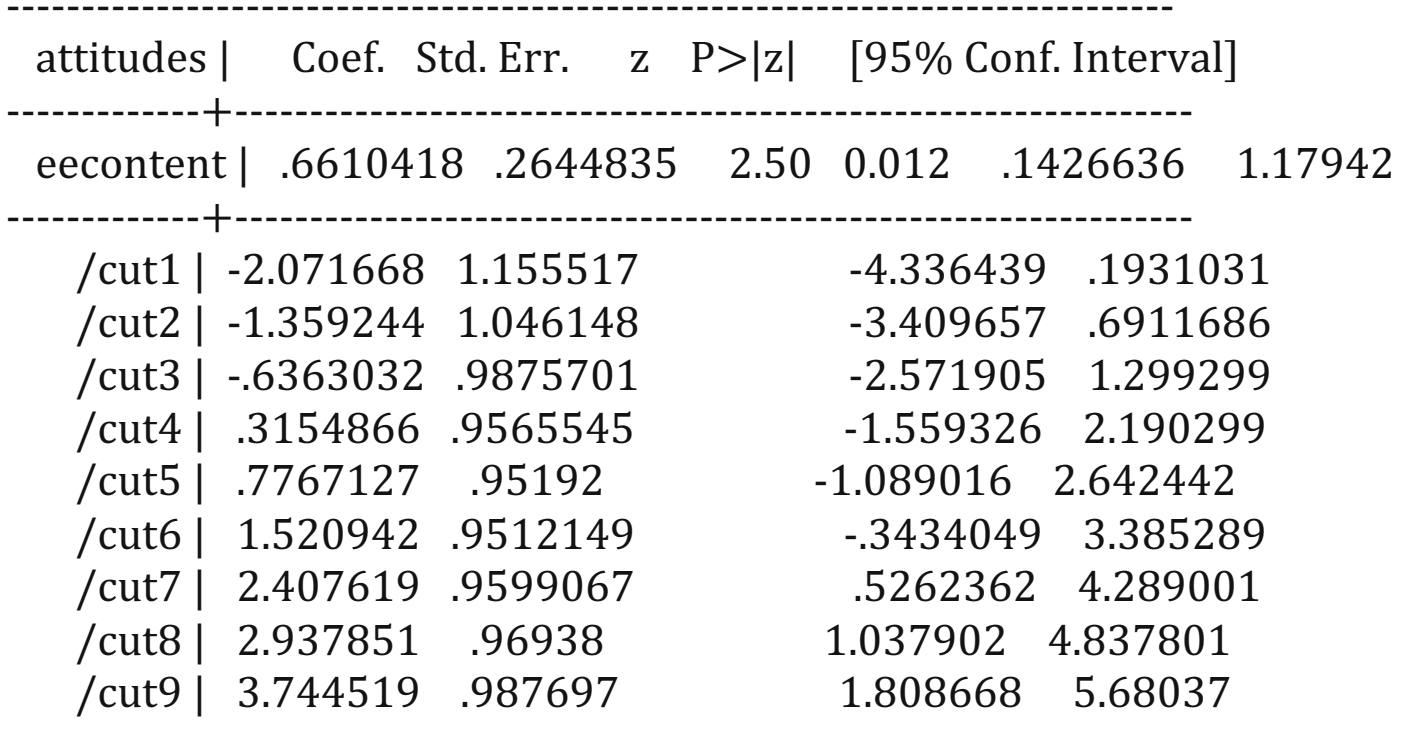

Table 4. Ordinal logistic regression logit ei attitudes ee content

Iteration 0: $\log$ likelihood $=-257.2653$

Iteration 1: $\log$ likelihood $=-242.74767$

Iteration 2: $\log$ likelihood $=-242.50424$

Iteration 3: $\log$ likelihood $=-242.50353$

Iteration 4: $\log$ likelihood $=-242.50353$

Ordered logistic regression $\quad$ Number of obs $=160$

$$
\begin{array}{lll}
\text { LR chi2(2) } & =29.52 \\
\text { Prob }>\text { chi2 } & =0.0000
\end{array}
$$




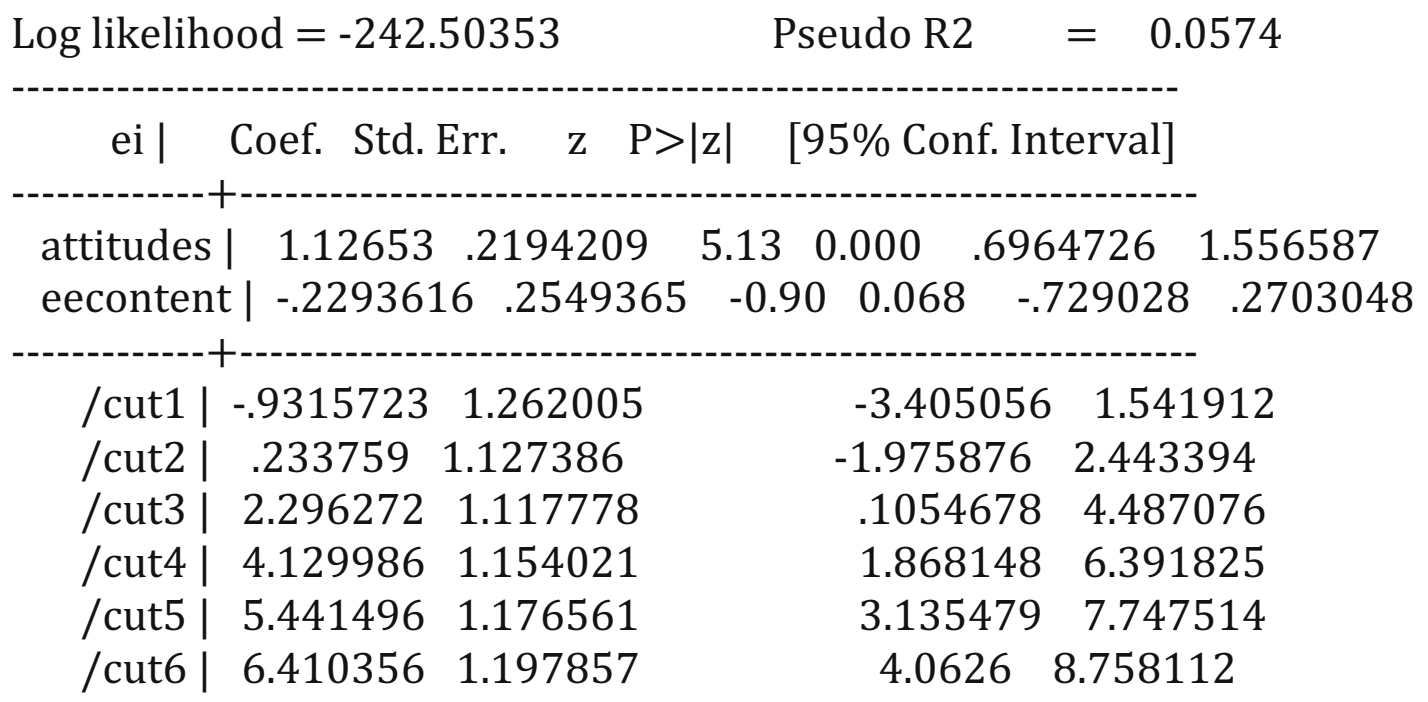

\section{CONCLUSION AND RECOMMENDATIONS}

Based on the findings of the above analysis the following conclusions were reached:

- Attitudes towards entrepreneurship strongly impact the decision of students to launch their business ventures;

- Attitudes in turn are significantly influenced by the perceived relevance of the entrepreneurship education content that students receive during their years of studies;

- Although the impact of educational content itself on entrepreneurial intention is not statistically significant, indirect impact of education via the attitudes construct can be substantial.

Taking into account the above analysis the governments together with higher educational institutions country-wide should carefully monitor and develop the most appropriate entrepreneurship courses and programs aimed at increasing positive attitudes towards entrepreneurship among students which in turn shall help to enhance entrepreneurial development in Uzbekistan.

\section{REFERENCES:}

1. Ajzen I., 1991, 'The theory of planned behaviour'

2. Blanchflower D., 2001 'Latent entrepreneurship across nations'

3. Fayolle A., 2019 'The Impact of Entrepreneurship Education on Entrepreneurial Attitudes and Intention: Hysteresis and Persistence'

4. Fayolla A. et Linan F., 'Beyond Entrepreneurial Intentions: Values and Motivations in Entrepreneurship'

5. Giacomin O., 2011, Entrepreneurial intentions, motivations and barriers: Differences among American, Asian and European students'

6. Hisrich D., 2005, The book 'Entrepreneurship'

7. Karimi S., 2016 'The Impact of Entrepreneurship Education: A Study of Iranian Students' Entrepreneurial Intentions and Opportunity Identification'

8. Krueger N. et al., 2010 'Competing models of entrepreneurial intention'

9. Kuratko D. 2005 'The Emergence of Entrepreneurship Education: Development, Trends, and Challenges'

10. Loof H. et al, 2008 'Does knowledge diffusion between university and industry increase innovativeness?' 
11. Passaro R. et al., 2018 'The impact of higher education on entrepreneurial intention and human capital'

12. Pruet M., 2009 'Explaining entrepreneurial intentions of university students: a cross-cultural study'

13. Tae Jun Bae et al, 2019 'The Relationship between Entrepreneurship Education and Entrepreneurial Intentions: A Meta-Analytic Review'

14. Zhang Y. et al., 2013 'The role of entrepreneurship education as a predictor of university students' entrepreneurial intention' 